\title{
Values and Intercultural Experiences Through Picture Books
}

\author{
María Tomé-Fernández, Juan Senís-Fernández, Diego Ruiz-Martín
}

\author{
Bringing intercultural experiences and their underlying values to globalized \\ classes through the use of picture books can be a powerful contribution to \\ intercultural education.
}

W hen entering a primary education classroom, María (first author) has observed students from diverse cultures with different customs and ways of living and understanding inherited from their parents. Some colleagues have told her about conflicts that have arisen in their classes because of the lack of understanding between students who are culturally different. Although those conflicts do not normally become alarming, they show the necessity of a preventive education that develops competences in intercultural students that allow them to coexist in a peaceful atmosphere.

Since María was a child, her fondness for picture books has helped her understand reality in a coherent way. Picture books transmitted and reinforced values that were important for her personal growth. As she is currently working with primary school students, she took the opportunity to use this type of book.

In one of these classrooms, there is a 10-year-old boy whose name is Ahmed and whose family comes from Morocco. Sometimes he is treated badly by other students because of his cultural and racial background. These uncomfortable and conflictive situations reaffirmed the need for an education based in intercultural values and led María to research the existence of picture books that represent the values of help, friendship, and empathy, among others.

Maria had to find stories that, through intercultural characters, were able to ensure the literary empathy needed to address these issues. As a teacher, her task was to read the books to analyze the responses of fifth-grade primary education students from a school in southern Spain, so she carried out semistructured interviews to do so.

\section{Review of Literature The Importance of Picture Books for an Intercultural Education}

Since ancient times, human beings have used the didactics of stories to explain different realities, first orally and later by writing. Literature became one of the main tools for acculturation because reality is reinterpreted through it, contributing to the knowledge and reflection of interculturality (Hoff, 2019; Yokota \& Teale, 2017).

Currently, literature is useful to prevent educational conflicts. For example, in culturally diverse societies, literary texts can be used to show collective diversity. Literature can also provide students with necessary strategies to embrace the pluralism that is present in those societies, advocating its democratic development (Coto \& Stewart, 2017).

In the difficult path toward interculturality and inclusion, different authors have recognized the great power of literature (Gilmore \& Howard, 2016; Kim, Wee, \& Lee, 2016; Monoyiou \& Symeonidou, 2016; Wang, 2014; Yulita, 2017). According to Martens et al. (2015), through reading literary texts, students acquire

Maria Tomé-Fernández is an associate professor in the Department of Research Methods and Diagnosis in Education at the University of Granada, Melilla, Spain; email mariatf@ugr.es.

Juan Senís-Fernández is an associate professor in the Department of Didactics of Languages and Human and Social Sciences at the University of Zaragoza, Teruel, Spain; email jsenis@unizar.es.

Diego Ruiz-Martin is a postgraduate student at the University of Granada, Spain; email diegoruizmartin75a correo.ugr.es. 
the necessary skills to learn how to respect, accept, and appreciate diversity as something positive for the collective development of the group. More specifically, picture books are considered one of the best means to promote underlying values in intercultural education because they are open to the imagination and require meaningful thoughts and a capacity for deep reflection (Encabo Fernández, López Valero, \& Jerez Martínez, 2012).

Therefore, picture books are an appropriate tool to teach positive attitudes toward interculturality. These attitudes are psychologically related to the acquisition of certain values (Village \& Francis, 2016) based on moral commitment to others (Higham \& Djohari, 2018) and on human rights (Espinel Bernal, 2017; Féron, 2014; Gordon, 2018). By showing characters who belong to different races, ethnicities, and cultures, picture books provide an opportunity to think critically about discrimination and social justice (Lysaker \& Sedberry, 2015; Seidel \& Rokne, 2011).

In addition, Boyd, Causey, and Galda (2015) stated that this type of intercultural literature has a commitment to diversity that encourages students to accept people who are different. This genre thus acts not only as a mirror in which students are reflected but also as a window through which they can see other cultural experiences (Wu, 2017), especially because text and images are intertwined in picture books (Nikolajeva \& Scott, 2013; Salisbury \& Styles, 2012; Van der Linden, 2015).

This trait can help improve intercultural education in Spanish schools, where an exclusive system is widely present (Osuna Nevado, 2012), although important preventive measures have been taken (Coronel \& Gómez-Hurtado, 2015). If they are not solved, educative problems with intercultural causes will increase in the coming years (Vitoroulis \& Georgiades, 2017); for example, according to the Spanish National Institute of Statistics (Instituto Nacional de Estadística, 2017), immigration in Spain will continue to grow at a vertiginous pace, enhancing the cultural diversity of schools.

\section{Intercultural Experiences and the Role of Teachers}

When teachers decide to deal with interculturality in their classrooms, they have to pay attention to issues such as racism, immigration, and discrimination, insofar as the omission of these topics can contribute to increasing social problems. The use of literature helps teachers deal with these issues, encouraging students to reflect on their knowledge and about the themes outlined in the books, sharing them and solving them with their peers (Osorio, 2018). In addition, books in which stories have been experienced by culturally diverse characters allow students to discover details about themselves that are seemingly insignificant, using those intercultural experiences to understand and make sense of the text and the images in the books (Lafferty, 2014).

If the chosen books are presented to students through the technique of reading aloud to the group, intercultural education will be enriched through debate and interaction (Braid \& Finch, 2015). In these environments, the teacher can be a leader to highlight important issues (Warner, Crolla, Goodwyn, Hyder, \& Richards, 2016).

Therefore, reading aloud will help students perceive the cultural interactions and traditions in a positive way (Hancock, 2016). That can also provoke an assimilation of values that allows students to empathize with the characters presented in the books. It also allows them to indirectly explore their thoughts and emotions, develop important ideas, and increase awareness, knowledge, understanding, and acceptance of oneself and others (Gilmore \& Howard, 2016).

\section{The Present Review}

The aim of this study is the promotion of intercultural education through picture books. Therefore, there is a need to look for useful literary tools that allow students to empathize with stories that reflect their own intercultural experiences or learn new approaches to problems that may arise. Likewise, we can discover students' perceptions of the values generated through these situations by reading aloud the selected books and subsequently conducting discussions on the different issues raised.

Insofar as picture books tell a story using both visual and textual codes, and thus the images contain information that is lacking in the texts, these books can be well understood even by those 
students whose mother tongue is different from the language spoken in their context. Although there are some studies analyzing picture books that promote intercultural education (Encabo Fernández et al., 2012; Lysaker \& Sedberry, 2015; Seidel \& Rokne, 2011; $\mathrm{Wu}, 2017)$, the questions that assess students after the read-aloud and discussions are generally not addressed. During this experience, and by answering those questions, it will be possible to determine if the selected books manage to introduce the students to the illustrated situation, producing values that will relate the immigrant protagonists to the selected literature and allow the teacher to establish dialogues concerning interculturality.

The picture books that were selected offer intercultural situations that can be familiar for both immigrant students and host country students. In the selection process, we considered that there has been an increase of immigrants for several decades now in Spain who come from the same places as the protagonists of the books (Instituto Nacional de Estadística, 2017). The immigration, and the cultural characteristics that it entails, is reflected in classrooms in Spain. This fact produces several degrees of intercultural conflicts that the selected books may improve or prevent with the transmission of values that promote the recognition of difference, national cohesion, and equality (Blum, 2014).

\section{Selection Criteria}

Several criteria were taken into account for choosing the picture books. First of all, the complexity of the story must fit the textual level of comprehension and the maturity of the students. Moreover, stories must arouse questions and discussions about interculturality, but always using respectful language. Books must also depict characters in a realistic way, without promoting patronizing feelings for the situations experienced by the protagonists or reinforcing stereotypes. Finally, the books must be seen as interesting, deep, and attractive, and they must be easy to find in bookshops or libraries.

\section{Search for Picture Books}

Once the criteria for bibliographic selection were established, the search for appropriate books started, from the school library to the university library and finally local libraries, with the help of the librarians who run them and online search engines. To do so, we used keywords related to interculturality, immigration, tolerance, multiculturalism, values, and so forth.

A list of books on culturally diverse literature (Boyd et al., 2015) was also used as a guide. However, most of the books were either difficult to find in Spanish or did not meet some of the established criteria. Amazon was also another source used, and some publishers that focus on the publication of these types of texts were chosen by consulting their websites (e.g., http://www.takatuka.cat).

We found 1,200 children's books whose topics dealt with interculturality, but only 53 were picture books. We read the books' abstracts and even leafed through some pages of the stories. The textual and visual qualities of each book were especially considered, and those books were read in more depth later on.

Two books were selected because they met the established criteria. More specifically, these two books were chosen because they show not only migrants' behaviors and feelings but also those of the people from the host country. They reflect the story of two African migrants from a realistic point of view, similar to the one that students can find in classrooms, and stimulate reflection on identity, diversity, and personal circumstances. They are also available online at reasonable prices. Additionally, these books are written in respectful language regarding cultural diversity and in a literary style that can be easily understood by fifth-grade students, and they tell highly interesting stories regarding the prevention of intercultural conflicts in the classroom.

\section{Selected Picture Books}

The two books selected for this didactic experience were El Día Que Saída Llegó (The Day Saída Arrived) by Susana Gómez Redondo (2012) and Mariama, Diferente Pero Igual (Mariama, Different but Equal) by Jerónimo Cornelles (2014).

At the beginning of El Día Que Saída Llegó (see Figure 1), Saída, a girl of Moroccan origin, is crying and her face fills up the whole page. It is through the words of Saída's schoolmate that the feelings of their friendship bloom poetically: "The day that Saída arrived, it seemed to me that she had lost every word" (Gomez Redondo, 2012, n.p.; our translation). During the rest of the book, her words fly up through the pages while the two friends, who are now smiling, enjoy each other's company. The powerful illustrations, along with the colors, shapes, and typography, reinforce the poetic tone of the narration. 
Figure 1

Cover of El Día Que Saída Llegó

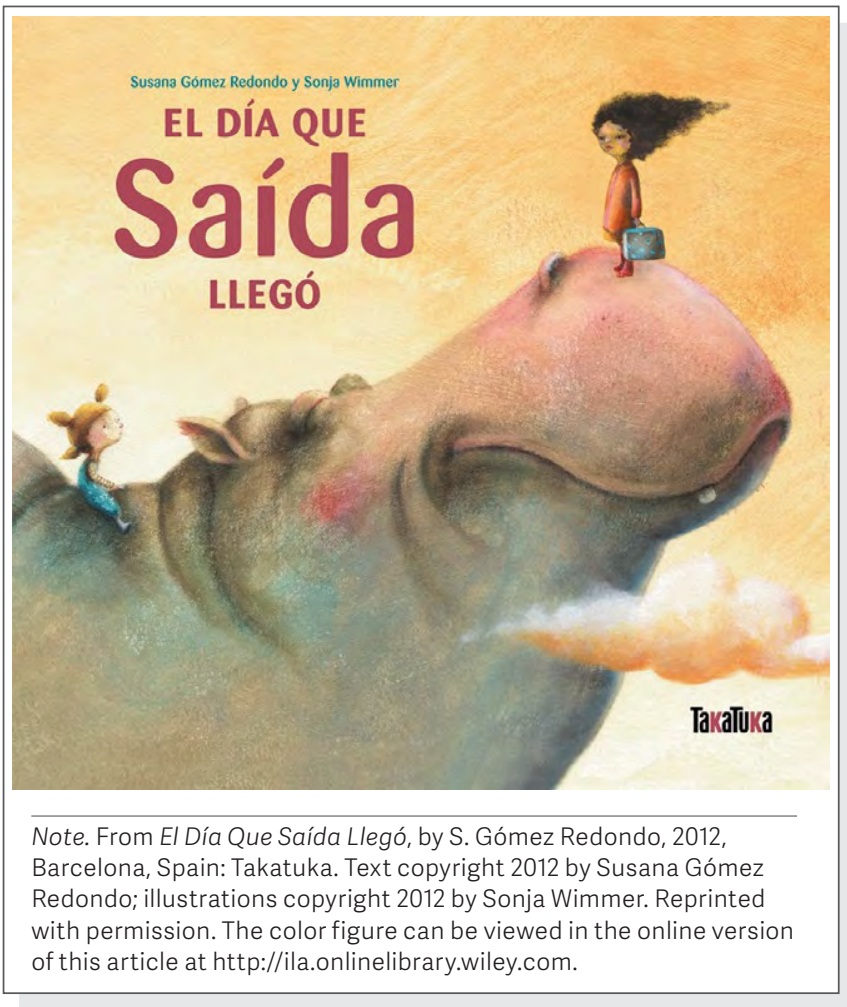

In Mariama, Diferente Pero Igual, everything is new to Mariama (see Figure 2). After a long journey from Africa, she begins to discover new languages and customs. With the help of her new friends, she makes an effort to learn the language and discovers that the only difference between them is their skin color. One of the most representative quotes from the book is "They were children who did not have to worry about anything else but being children" (Cornelles, 2014, n.p.; our translation), which reflects on the complexity of the protagonist's childhood.

In this book, text and images come together to tell a story about identity, the integration process, and the importance of companionship. Furthermore, the illustrations show typical food, drinks, instruments, and games from Mariama's country. This fact makes it easier for Spanish students to think about diversity of traditions.

\section{Procedure: Read-Aloud and Discussion}

Diego (third author) read the selected books aloud to students. As he was reading, he paused to ask the students questions about the situations in the
Figure 2

Cover of Mariama, Diferente Pero Igual

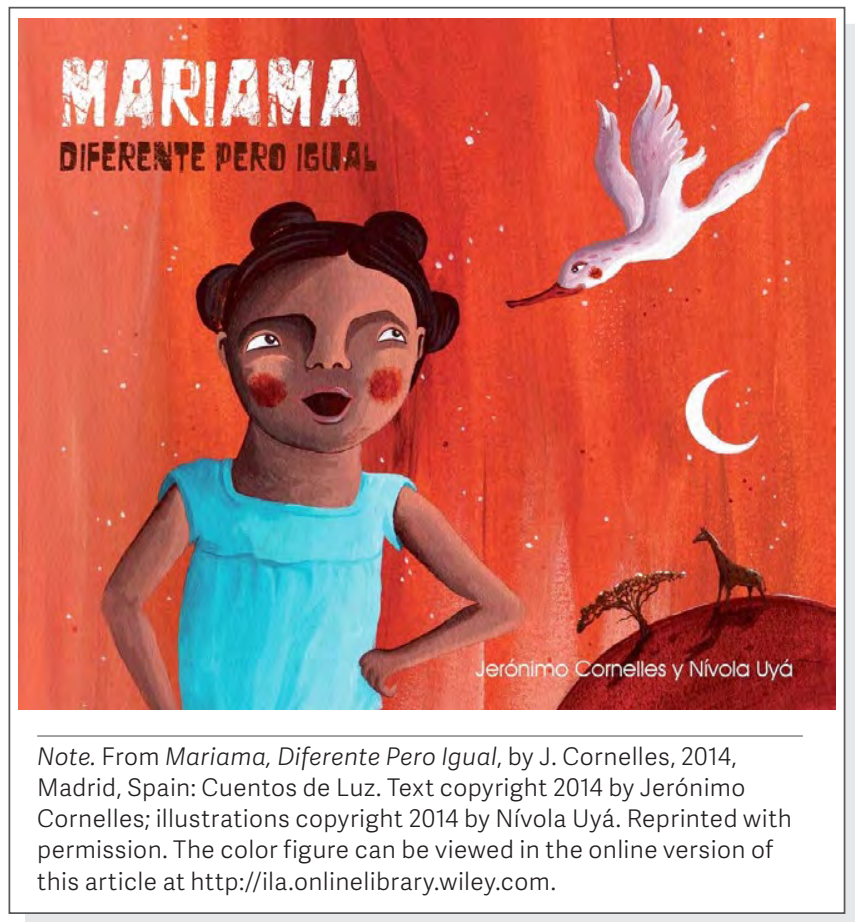

book and to show the images. The questions were previously established in the initial semistructured interview. Some examples are "What is the reaction of Saída's partner when she arrives in the classroom?" and "When does the sentence "For Mariama, all was new' appear in the book, and what exactly does it mean?"

Sometimes students' answers generated debate, a deepening in the subject, and other questions that completed the initial questions. These new questions helped the students think more specifically about intercultural experiences and values. Examples of these are "What would be your reaction in the same situation?" and "Why do you think Mariama and her parents decided to go to another country?"

\section{Method}

\section{Participants}

This study used a nonprobability sampling (convenience) of 30 students in fifth grade. The average age of the participants was 10.46 years ( $S D=0.51$ years); $43.3 \%$ were male $(n=13)$ and $56.6 \%$ female $(n=17)$. Regarding ethnicity, $23.3 \%$ of the students $(n=7)$ were African migrants, $6.6 \%(n=2)$ were Latin American, $6.6 \%(n=2)$ were European, and 63.3\% $(n=19)$ were 
Spanish. Moreover, 70\% $(n=21)$ of the participants belonged to a family with a low social and cultural level, and $30 \%(n=9)$ spoke a first language that is not Spanish.

The survey took place in a public school in Granada, Spain, located in a neighborhood with a significant presence of African and Latino American migrants who arrived in Spain looking for a better future (Instituto de Estadística y Cartografía de Andalucía, 2018).

\section{Instrument}

The data collection was carried out through a semistructured interview. This was initially composed of 14 questions that were amplified with additional questions after it was implemented in the classrooms (Conzelmann \& Keye, 2014).

Prior to implementation, the instrument was validated by 10 experts (Lissitz \& Samuelsen, 2007), who established the content validity index for each element (I-CVI) and the content validity index for the interview in general (S-CVI). With the I-CVI, the percentage was obtained by experts who evaluated the items as quite relevant ( 3 points) or more relevant (4 points) in a Likert-type scale. The questions that obtained an I-CVI less than .78 were eliminated, as contemplated in related literature (Polit, Beck, \& Owen, 2007). In addition, by evaluating the average of each I-CVI, the content validity index for the interview in general was obtained as S-CVI $=.90$, which shows excellent evidence of content validity (Polit et al., 2007).

After implementation, the final version of the interview was composed of 20 items and S-CVI $=.93$, so high levels of content validity were achieved. The final instrument is shown in Table 1.

\section{Data Analysis}

The results were assessed through a thematic analysis of the interviews in Spanish (McKillop, McCrindle, Dimitropoulos, \& Kovacs, 2018) and translated into English to be shown in the present article. (Students' answers were also translated.)

The procedure was conducted as follows: First, the interviews were manually transcribed; second, initial codes were applied to the data; third, the codes were merged with similar contents (the ones that show values and the ones that show intercultural experiences); finally, subthemes were identified and redefined.

\section{Table 1 Questions Asked of Students in Final Semistructured Interview}

\begin{tabular}{|c|c|}
\hline Item & Question \\
\hline 1 & $\begin{array}{l}\text { Why is Saída crying at the beginning of the } \\
\text { picture book? }\end{array}$ \\
\hline 2 & How is she feeling? \\
\hline 3 & $\begin{array}{l}\text { Why did Saída's friend decide to learn her } \\
\text { language and her birth country? }\end{array}$ \\
\hline 4 & $\begin{array}{l}\text { What do you think of migrants' need to learn a } \\
\text { new language? }\end{array}$ \\
\hline 5 & $\begin{array}{l}\text { When does the sentence "She had lost every } \\
\text { word" appear in the book, and what is the } \\
\text { exact meaning? }\end{array}$ \\
\hline 6 & $\begin{array}{l}\text { Do you think it is easy for the main character } \\
\text { to learn a new idiom? }\end{array}$ \\
\hline 7 & $\begin{array}{l}\text { What is the reaction of Saída's partner when } \\
\text { she arrives in the classroom? }\end{array}$ \\
\hline 8 & $\begin{array}{l}\text { What would be your reaction in the same } \\
\text { situation? }\end{array}$ \\
\hline 9 & $\begin{array}{l}\text { Do you think there are kids in your school who } \\
\text { experience the same situation? }\end{array}$ \\
\hline 10 & $\begin{array}{l}\text { Do you think it would be easy to become } \\
\text { Saída's friend? }\end{array}$ \\
\hline 11 & $\begin{array}{l}\text { Do you think that one of your partners may } \\
\text { experience something similar to what Saída is } \\
\text { experiencing in the book? }\end{array}$ \\
\hline 12 & $\begin{array}{l}\text { Imagine that you arrive at a new school in } \\
\text { another country. What would be more difficult } \\
\text { for you? }\end{array}$ \\
\hline 13 & $\begin{array}{l}\text { How would you like to be treated when } \\
\text { arriving in a new country? }\end{array}$ \\
\hline 14 & $\begin{array}{l}\text { Why do you think Mariama has a bad time } \\
\text { when arriving in her new country? }\end{array}$ \\
\hline 15 & $\begin{array}{l}\text { When does the sentence "For Mariama, } \\
\text { all was new" appear in the book, and what } \\
\text { exactly does it mean? }\end{array}$ \\
\hline 16 & $\begin{array}{l}\text { Why do you think Mariama and her parents } \\
\text { decided to go to another country? }\end{array}$ \\
\hline 17 & $\begin{array}{l}\text { What are the advantages and disadvantages } \\
\text { of having a partner like Mariama? }\end{array}$ \\
\hline 18 & $\begin{array}{l}\text { How was Mariama feeling during the first days } \\
\text { of school? }\end{array}$ \\
\hline 19 & Why do you think she was feeling that way? \\
\hline 20 & $\begin{array}{l}\text { How could you help Mariama if she were in your } \\
\text { class? }\end{array}$ \\
\hline
\end{tabular}


The reliability of the analysis of the data was analyzed. The concordance of codes between researchers ranged from $K \geq 86$ to $K \geq 92$. The discordant codes were changed for inclusion in the analysis. Finally, an external evaluator analyzed $50 \%$ of the interviews, and with the researchers, he found the concordance interval $\mathrm{K} \geq 88$.

\section{Analysis of the Answers Provided by the Students}

\section{Theme: Intercultural Experiences}

Subtheme: Feelings. Both main characters in the picture books, Saída and Mariama, are crying at the beginning of the book. These are visually very powerful sequences, and in the classroom, the questions make strong use of them as a starting point.

The 30 students explained that Mariama and Saída could feel this way because they left their countries and had a bad time when they arrived at their destination country. For example, Yolanda said, "She [Mariama] feels bad and sad because she is missing her country, the African moon, her grandparents, and the stories they read to her."

Subtheme: Language and Communication. The questions on this subtheme were aimed at reflecting on the difficulty of learning a new language. Although all students agreed on this, some of them went further and made comments on deeper aspects. For example, Raúl said, "She [Saída] probably feels inferior to the rest because she is not able to interact with them."

In the specific case of Saída, the students were asked about what they believed it meant that she had "lost every word" (as stated in the book). All 30 participants agreed on how difficult it is for Saída to learn Spanish. Furthermore, one of the students said that it would be easier for her to learn with a classmate's help.

Subtheme: Customs and Lifestyle. In the semistructured interview, students were asked about the meaning of the sentence "For Mariama, all was new." Seven students suggested that it referred to the way streets and houses look, 10 students said it was related to customs, meals, dishes, and utensils, and another 11 said it had to do with the language or friends.

Two students gave more personal responses. Lucas said, "She won't be able now to see the stars as she could see them in Africa." Nora said, "Her skin color, her personality."
Subtheme: Reasons for Migrating. The disparity of opinions that originated in the two previous questions resulted in another discussion and raised the following question: "Why do you think Mariama and her parents decided to go to another country?"

Almost all of the students (25) agreed that work was the reason; four students suggested that it might be because of a war, to know other places, and one said it could be for tourism. However, after talking about it, the other four members of the group rejected the last suggestion.

\section{Theme: Values}

Subtheme: Help. The first questions about values were aimed at discovering students' perception of the arrival of the two girls to their new countries and the reaction students would have if this happened in their classroom. In the case of Saída, a classmate helps her when she arrives at her new school. All 30 students agreed that Saída's classmate is helping her throughout the inclusion process. In addition, 24 students showed willingness to help if this situation took place in their classroom.

These responses began a discussion about the way someone reacts when he or she is sad and the difficulties that can emerge when trying to help. For example, Daniel said, "Even if someone is not able to speak our language, it is noticeable when a person is sad, then we would realize and be able to help."

Julia talked about an intercultural experience that took place in the classroom: "Last year, a boy from Morocco was in our classroom to learn our language. We all helped him, and now he is able to speak better."

Subtheme: Friendship. The semistructured interview was extended with a specific question ("Do you think it would be easy to become Saída's friend?") to go deeper into the value of friendship. The answers provided were contradictory. More specifically, 11 students had a positive perspective and 19 maintained a negative one.

An example of this is Jose's answer: "Being friends with her would be difficult because she can't really talk, and some students could treat that person in a discriminatory way." Also, Sofia said, "If we helped her and she learned the language, it would be just as easy as making friends with other children."

Regarding Mariama, most of the answers (24) confirmed that the advantages of having her as a friend would be the fact of knowing more about her 
town, her journey, and what Africa is like. In addition, 13 students added that they could also learn about Mariama's customs and learn some words in her mother tongue.

Subtheme: Empathy. In relation to this, and in the case of Mariama, some questions were focused on exploring whether students could recognize the feelings Mariama experienced during the first days of school and if they could give some ideas on how to help the protagonist if she were in their classroom.

In the book, there are some images where Mariama is sitting next to her classmates and speaking in a language unknown to her. All of the students thought that she felt sad because it was hard to understand the others. Eight students said that she could also feel uncomfortable because the classmates looked at her differently. Then, the students offered some solutions, appealing to the values of friendship and integration to help Mariama in case she came to their class. For example, Miguel said, "We could make friends with her and help her with the language and class activities."

Otherwise, as for Saída, the students were asked if her situation could happen to other students in the school. One of the answers was "Yes, there are children who come from another country. However, some may have possibly learned some Spanish before coming here."

The discussion raised in situ the following questions: "Imagine that you arrive at a new school in another country. What would be more difficult for you?" and "How would you like to be treated when arriving in a new country?" The most significant answers were Carmen's and Yolanda's. Carmen said, "To me, the hardest thing would be to make friends because of the language. Starting over is very complicated." Yolanda said, "We would like them to welcome us with a smile and that they would like to become our friends."

\section{Conclusions}

After completing the whole process of research concerning this didactic experience, our conclusions focus on two different aspects: the students' answers and our learning.

By analyzing students' answers, it is clear that they are generally conscious of Saída's and Mariama's difficulties as migrants. For example, most of them consider looking for a better future as the main reason for migrating. Above all, they mention reasons concerning employment. Moreover, students are aware of the cultural shock produced when arriving in a new country on a new continent. They are also conscious of the sadness that can be generated by changing customs, food, and friends and the fact of not being fluent in the new country's language. With particular attention to communication issues, after reading the two books students were clearly aware of the importance of speaking the official language of the country in order to fit in, and their answers insist on the importance of helping the newcomers solve this problem. Finally, the students' comments clearly show empathy with Saída and Mariama's problems regarding adaptation issues. They see themselves as a key instrument for the integration of the newcomers and consider friendship as a fundamental piece of that and for interchanging intercultural knowledge. All in all, on reflecting on the selected books, students were provided with important values to prevent intercultural conflicts, such as helpfulness, friendship, and empathy.

Besides all that, the process allowed us to be conscious of students' opinions, mostly thanks to two different actions: reading the books aloud and conducting semistructured interviews afterward. The discussions generated by this last technique were conducted in an objective way, without judging students' answers and avoiding personal opinions. All these have stimulated and permitted students' free speech.

Results from this study provide qualitative evidence that picture books can be a fun and engaging method to spark productive discussions and raise student awareness and sensitivity to the plight of incoming immigrant populations. In addition, the research could test the effectiveness of using picture books in classrooms, insofar as their combination of text and images can offer more information to the students in the easiest way. The chosen picture books opened doors to new perspectives on cultural integration. Consequently, the picture books' selection criteria can be considered valuable and efficient for finding the right materials to work on intercultural education in primary education.

It is certainly evident that the use of selected picture books contributed to working on intercultural issues with primary education students in Spain, even though this evidence cannot be applied to other Spanish contexts. Therefore, it is necessary to enhance the sample and the geographic location for further study. 


\section{TAKE ACTION!}

1. Preparation: Search for and select picture books that properly represent the cultural diversity of your classroom. In this experience, books that reflected African migration were selected to reflect the situation in the classroom.

2. Recognition: Perform a dramatized reading to share the students' initial responses to the text and illustrations. In this case, the reading was useful to talk about intercultural problems in the classroom.

3. Deepening: Work on development activities regarding the text in which the benefits of intercultural coexistence are reflected. Use techniques such as role-playing, debating, or presenting real biographies. In this case, general questions arose continually to debate in the classroom.

4. Critical level: Propose an investigation on the origin of the protagonists in picture books. In this experience, through reading aloud, questions about the origin of Saída and Mariama were especially emphasized.

5. Social development: Focus on values in the classroom by taking advantage of the coexistence of culturally diverse students and by using games and group work. In the survey, the answers reflected values related to help, friendship, and empathy.

\section{REFERENCES}

Blum, L. (2014). Three educational values for a multicultural society: Difference recognition, national cohesion, and equality. Journal of Moral Education, 43(3), 332-344. https:// doi.org/10.1080/03057240.2014.922057

Boyd, F.B., Causey, L.L., \& Galda, L. (2015). Culturally diverse literature: Enriching variety in an era of Common Core State Standards. The Reading Teacher, 68(5), 378-387. https:// doi.org/10.1002/trtr.1326

Braid, C., \& Finch, B. (2015). “Ah, I know why...": Children developing understandings through engaging with a picture book. Literacy, 49(3), 115-122. https://doi.org/10.11 11/lit.12057

Conzelmann, K., \& Keye, D. (2014). Which aspects of a semistructured interview, besides cognitive ability tests, contribute incrementally to predicting the training success of air traffic controller trainees? International Journal of Selection and Assessment, 22(3), 240-252. https://doi.org/10.1111/ijsa.12073

Coronel, J.M., \& Gómez-Hurtado, I. (2015). Nothing to do with me! Teachers' perceptions on cultural diversity in Spanish secondary schools. Teachers and Teaching, 21(4), 400-420. https://doi.org/10.1080/13540602.2014.968896

Coto, M., \& Stewart, M.A. (2017). Literatura multicultural en español: ¿Abriendo ventanas o reforzando estereotipos? [Multicultural literature in Spanish: Opening windows or reinforcing stereotypes?]. Journal of Latinos and Education, 16(2), 156-163. https://doi.org/10.1080/15348431.2016.1205989

Encabo Fernández, E., López Valero, A., \& Jerez Martínez, I. (2012). Un estudio sobre el uso de álbumes ilustrados en educación primaria para la mejora de la competencia intercultural: Una perspectiva europea [A study of the use of picture books in primary education in order to improve intercultural competence: A European perspective]. Revista de Educación, 358, 406-425.

Espinel Bernal, O.O. (2017). Governmentality, democratic state, and education in human rights. Educational Philosophy and Theory, 49(7), 681-690. https://doi.org/10.1080/00131857. 2016.1204734

Féron, H. (2014). Human rights and faith: A "world-wide secular religion"? Ethics \& Global Politics, 7(4), 181-200. https://doi.org/ 10.3402/egp.v7.26262

Gilmore, L., \& Howard, G. (2016). Children's books that promote understanding of difference, diversity, and disability Journal of Psychologists and Counsellors in Schools, 26(2), 218251. https://doi.org/10.1017/jgc.2016.26

Gordon, M. (2018). In search of a universal human rights metaphor: Moral conversations across differences. Educational Philosophy and Theory, 50(1), 83-94. https://doi.org/10. 1080/00131857.2017.1336920

Hancock, A. (2016). Creating a dialogic space for research: A reading conference in a Chinese complementary school. Language and Education, 30(2), 126-142. https://doi.org/10.10 80/09500782.2015.1103258

Higham, R., \& Djohari, N. (2018). From voting to engaging: Promoting democratic values across an international school network. Oxford Review of Education, 44(6), 669-685. https://doi.org/10.1080/03054985.2018.1433649

Hoff, H.E. (2019). Fostering the "intercultural reader"? An empirical study of socio-cultural approaches to EFL literature. Scandinavian Journal of Educational Research, 63(3), 443-464. https://doi.org/10.1080/00313831.2017.1402366

Instituto de Estadística y Cartografía de Andalucía. (2018). Estadísticas sobre población extranjera [Statistics on foreign population]. Seville, Spain: Consejería de Economía, Hacienda y Administración Pública. Retrieved from https:// www.juntadeandalucia.es/institutodeestadisticaycartog rafia/poblaextran/index.htm

Instituto Nacional de Estadística. (2017). Cifras de población a 1 de julio de 2017: Estadística de migraciones [Population figures as of July 1, 2017: Migration statistics]. Madrid, Spain: Author. Retrieved from http://www.ine.es/dyngs/INEbase/ es/operacion.htm?c=Estadistica_C\&cid $=1254736177000 \& m e$ nu=ultiDatos\&idp $=1254735573002$

Kim, S.J., Wee, S.-J., \& Lee, Y.M. (2016). Teaching kindergartners racial diversity through multicultural literature: A case study in a kindergarten classroom in Korea. Early Education and Development, 27(3), 402-420. https://doi.org/10.1080/1 0409289.2015 .1069110

Lafferty, K.E. (2014). "What are you reading?": How school libraries can promote racial diversity in multicultural literature. Multicultural Perspectives, 16(4), 203-209. https:// doi.org/10.1080/15210960.2014.951888

Lissitz, R.W., \& Samuelsen, K. (2007). A suggested change in terminology and emphasis regarding validity and education. Educational Researcher, 36(8), 437-448. https:// doi.org/10.3102/0013189X07311286

Lysaker, J., \& Sedberry, T. (2015). Reading difference: Picture book retellings as contexts for exploring personal meanings of race and culture. Literacy, 49(2), 105-111. https:// doi.org/10.1111/lit.12055

Martens, P., Martens, R., Doyle, M.H., Loomis, J., Fuhrman, L., Furnari, C., ... Stout, R. (2015). Building intercultural understandings through global literature. The Reading Teacher, 68(8), 609-617. https://doi.org/10.1002/trtr.1359

McKillop, A., McCrindle, B.W., Dimitropoulos, G., \& Kovacs, A.H. (2018). Physical activity perceptions and behaviors among young adults with congenital heart disease: A mixed-methods study. Congenital Heart Disease, 13(2), 232240. https://doi.org/10.1111/chd.12553 
Monoyiou, E., \& Symeonidou, S. (2016). The wonderful world of children's books? Negotiating diversity through children's literature. International Journal of Inclusive Education, 20(6), 588-603. https://doi.org/10.1080/13603116.2015.1102338

Nikolajeva, M., \& Scott, C. (2013). How picture books work. London, UK: Routledge.

Osorio, S.L. (2018). Multicultural literature as a classroom tool. Multicultural Perspectives, 20(1), 47-52. https://doi.org/1 $0.1080 / 15210960.2018 .1408348$

Osuna Nevado, C. (2012). En torno a la educación intercultural: Una revisión crítica [Intercultural education: A critical review]. Revista de Educación, 358, 38-58.

Polit, D.F., Beck, C.T., \& Owen, S.V. (2007). Is the CVI an acceptable indicator of content validity? Appraisal and recommendations. Research in Nursing \& Health, 30(4), 459467. https://doi.org/10.1002/nur.20199

Salisbury, M., \& Styles, M. (2012). Children's picturebooks: The art of visual storytelling. London, UK: Laurence King.

Seidel, J., \& Rokne, A. (2011). Picture books for engaging peace and social justice with children. Diaspora, Indigenous, and Minority Education, 5(4), 245-259. https://doi.org/10.1080/1 5595692.2011.606007

Van der Linden, S. (2015). Álbum(es). Barcelona, Spain: Ekaré.

Village, A., \& Francis, L.J. (2016). The development of the Francis Moral Values Scales: A study among 16- to 18-yearold students taking religious studies at A level in the UK. Journal of Beliefs \& Values, 37(3), 347-356. https://doi.org/ 10.1080/13617672.2016.1232568

Vitoroulis, I., \& Georgiades, K. (2017). Bullying among immigrant and non-immigrant early adolescents: Schooland student-level effects. Journal of Adolescence, 61, 141-151. https://doi.org/10.1016/j.adolescence.2017.10.008

Wang, Y. (2014). Learning across borders-Chinese migrant literature and intercultural Chinese language education. Language and Intercultural Communication, 14(3), 339-351. https://doi.org/10.1080/14708477.2014.901598

Warner, L., Crolla, C., Goodwyn, A., Hyder, E., \& Richards, B. (2016). Reading aloud in high schools: Students and teachers across the curriculum. Educational Review, 68(2), 222-238. https://doi.org/10.1080/00131911.2015.1067881

Wu, J.-F. (2017). Teaching university students cultural diversity by means of multi-cultural picture books in Taiwan. Multicultural Education Review, 9(4), 249-269. https:// doi.org/10.1080/2005615X.2017.1383812

Yokota, J., \& Teale, W.H. (2017). Striving for international understanding through literature. The Reading Teacher, 70(5), 629-633. https://doi.org/10.1002/trtr.1557

Yulita, L. (2017). New perspectives on intercultural language research and teaching: Exploring learners' understandings of texts from other cultures. Language and Intercultural Communication, 19(2), 220-222. https://doi.org/10.1080/14708 477.2017.1365104

\section{LITERATURE CITED}

Cornelles, J. (2014). Mariama, diferente pero igual [Mariama, different but equall. Madrid, Spain: Cuento de Luz.

Gómez Redondo, S. (2012). El día que Saída llegó [The day Saída arrived]. Barcelona, Spain: Takatuka.

\section{MORE TO EXPLORE}

- Zinkin, C. (2017, May 22). Using picture books for discussion and critical thinking [Web log post]. Retrieved from: http://www.fcbg.org.uk/using-pict urebooks-for-discussion-and-critical-thinking/ (This blog post provides information about the usefulness of reading aloud in the classroom and includes practical examples to encourage discussions with students after these readings.)

- UNESCO. (2006). UNESCO guidelines on intercultural education. Paris, France: Author. Retrieved from http: //unesdoc.unesco.org/images/0014/001478/147878e. pdf (This document synthesizes and serves as a guide to the legislative aspects of intercultural education.)

- "Promoting Diversity in the Classroom and School Library Through Social Action," a ReadWriteThink.org lesson plan by Michelle Ota: http://www.readwritet hink.org/classroom-resources/lesson-plans/promot ing-diversity-classroom-school-317.html (This lesson plan analyzes stereotypes depicted in several picture books and proposes comparative activities.)

- The International Board on Books for Young People: http://www.ibby.org (This organization's website offers a range of international literature aimed at early childhood and youth education.) 